\title{
Is English becoming a threat to the existence of indigenous languages in institutions of higher learning in South Africa?
}

\author{
Anzanilufuno Munyai \\ $L L B, L L M, L L D$ \\ Lecturer, Practical Business Law Department, University of Johannesburg (APK) \\ Moses Retselisitsoe Phooko \\ Dip Human Rights, LLB LLM LLD \\ Associate Professor, Department of Private Law, University of Johannesburg (APK)
}

\begin{abstract}
SUMMARY
This article provides a critique of the judgment of the Constitutional Court of South Africa in Gelyke Kanse v Chairperson of the Senate of the University of Stellenbosch ${ }^{1}$ with specific reference to the concept of transformative constitutionalism and the use of indigenous languages in tertiary education. The discussion further highlights the significant role played by one's own language in his or her day-to-day life encounters and argues that the wait has been too long to have one of the indigenous languages fully utilised in one of the tertiary institutions, amongst others. Finally, the paper recommends that the use of indigenous languages at institutions of higher learning needs to be given urgent attention by all stakeholders and can no longer remain at the mercy of those who are tasked with language policies at tertiary institutions.
\end{abstract}

\section{Introduction}

Over the past nine years, the courts have been called upon several times to decide on issues that involved access to education, language barriers, culture and the need to transform a society from the wrongdoings of the pre constitutional era. ${ }^{2}$ According to Majidi, "[e]very language (either minority or majority) carries a part of human culture, identity, history and civilisation, thus their maintenance and revitalisation is significant". 3 Majidi's view is tenable in that language plays a significant role in one's life and therefore needs to be promoted at all levels.

12019 (12) BCLR 1479 (CC).

2 See for example; Governing Body of the Juma Musjid Primary School \& Others $v$ Essay N.O. 2011 (8) BCLR 761 (CC); Afriforum v Chairman of the Council of the University of South Africa (54450/2016) [2018] ZAGPPHC 295; Afriforum and Another $v$ Chairperson of the Council of the University of Pretoria (54451/ 2016) [2016] ZAGPPHC 1030; [2017] 1 All SA 832 (GP).

3 Majidi "English as a Global Language; Threat or Opportunity for Minority Languages?" 2013 MJSS 37.

How to cite: Munyai \& Phooko 'Is English becoming a threat to the existence of indigenous languages in institutions of higher learning in South Africa?' 2021 De Jure Law Journal 298-327 http://dx.doi.org/10.17159/2225-7160/2021/v54a18 
Language is a unified system of words that enables people to think, share meaning, define reality, and affords them an opportunity to express emotions, ideas, experience and evaluate surroundings. ${ }^{4}$ Colonialism in Africa and apartheid in South Africa prevented the development of indigenous languages in both primary and tertiary education. ${ }^{5}$

In South Africa, the use of and dominance of Afrikaans as a primary language of instruction in universities has prevented those who are unable to communicate in Afrikaans from accessing and learning in certain universities. ${ }^{6}$ Afrikaans is one of the minority languages. $\mathrm{A}$ minority language is often associated with demography and it is a language spoken by fewer people than those in other groups. ${ }^{8}$ From a broader perspective, a minority language may also be understood as a language containing characteristics grouped in terms of ethno-social parameters, which are namely;

a Self-categorisation

b Common descent

c Distinctive linguistic, cultural or historical traits related to language

d Social organisation of the interaction of language groups in such a fashion that the group becomes place in a minority position. ${ }^{9}$

In post-apartheid South Africa, the dominant languages are English and Afrikaans. ${ }^{10}$ These two languages are "the languages of the socioeconomically prevailing white minorities' at the expense of other African languages" ${ }^{11}$ to which the latter continue to remain or are perceived as societally inferior and insignificant. The consequence of this predicament is that other African languages are subjected to being utilised in domestic and informal domains in the social lives of their speakers, whereas education in higher education continues to be dominantly offered in English and Afrikaans. ${ }^{12}$

4 Steinberg An Introduction to Communication Studies (2007) 115.

5 Mosweunyane "The African Educational Evolution: From Traditional Training to Formal Education” 2013 HES 55.

6 AfriForum v University of the Free State 2018 (2) SA 185 (CC) para 45.

7 Le Cordeur Afrikaans as medium of instruction within a transformed higher education system in South Africa with special reference to Stellenbosch University in Wolhuter, CC (red.). SAERA Konferensieboek: Educational Research in South Africa: Practices and Perspectives (2013) 62.

8 See Cenoz "Minority language and sustainable translanguaging: Threat or opportunity" 2017 JLIE 901.

9 Owens Arabic as a Minority Language (2013) 2.

10 See Ridge "Mixed Motives: Ideological Elements in the Support for English in South Africa" in Ricento, Ideology, Politics, and Language Policies: Focus on English (2000) 153; and Zegeye and Harris, Media, Identity and the Public Sphere in Post-Apartheid South Africa: An Introduction (2003) 14.

11 Tshivenda, Xitsonga, IsiXhosa, IsiZulu, IsiNdebele, Sepedi, SeSotho, Setswana, Sign language, SiSwati.

12 Prah, "The Challenge of Language in post-apartheid South Africa" (2018-0322) Litnet https://www.litnet.co.za/challenge-language-post-apartheid-southafrical (accessed 2019-12-30). 
The last university to offer education fully in Afrikaans on all academic streams is the Stellenbosch University (the University). The challenges that arose in this instance was that Afrikaans negatively affected access to higher education, as it is a language spoken by the minority group amongst others. In our view, under the current constitutional dispensation, it is no longer tenable for Afrikaans to be retained as the primary medium of instruction.

The main purpose of this paper is to critically discuss the challenges associated with the use of one language, Afrikaans, as a primary medium of instruction in the higher education sector, with specific reference to the case of Gelyke Kanse $v$ Chairperson of the Senate of the University of Stellenbosch. ${ }^{13}$ The discussion is divided into seven sections. Part 2 provides an overview of the facts of the case in the High Court, part 3 discusses the Constitutional Court judgments and part 4 is an analysis of the Constitutional Court judgment, with reference to the concept of transformative constitutionalism. Part 5 evaluates how the courts have dealt with the issue of using indigenous languages and the extent to which the use of indigenous languages was promoted. Part 6 is an evaluation of the cases. Part 7 evaluates the measures taken by the government in the promotion of indigenous languages. Part 8 is the recommendations and conclusion.

\section{The case before the High Court}

The applicants in this matter are a voluntary association, which promotes Afrikaans and other indigenous languages, together with diverse students at the University who wish to receive education in Afrikaans. The respondent is the University.

According to the 2014 Language Policy, Afrikaans and English were languages of learning and teaching. ${ }^{14}$ However, during the course of 2015 and 2016, the 2014 Language Policy resulted in the apparent exclusion of the majority of Black students who were not proficient in Afrikaans. ${ }^{15}$ Given the aforesaid exclusion of Black students, the University decided to adopt the 2016 Language Policy which would result in a " $100 \%$ English offering, but would not similarly increase the Afrikaans offering". 16 The applicants are aggrieved by the decision of the University to adopt the 2016 Language Policy, because they are under the impression that it will "cause the 'virtual exclusion' of Afrikaans". ${ }^{17}$ They therefore wanted the High Court to review and set aside the 2016 Language Policy and to reinstate the 2014 Language Policy.

132019 (12) BCLR 1479 (CC).

14 Gelyke Kanse vs Chairman of the Senate of the Stellenbosch University 2017 JDR 1687 (WCC) para 50.

15 Para 50.

16 Para 52.

17 Para 53. 
The issues before the High Court were inter alia whether adopting the 2016 Language Policy constituted an administrative action, ${ }^{18}$ and if so, whether the decision was substantively irrational. ${ }^{19}$ Further, whether the 2016 Language Policy violated section 29(2) of the Constitution, which guarantees everyone the right to receive an education in the official language or languages of their choice in public educational institutions where it is reasonably practicable? ${ }^{20}$

The University inter alia contended that the applicants were mistaken in that the 2016 Language Policy, "does not reduce the Afrikaans offering" at the University. ${ }^{21}$ Rather, the objective of the policy "is to maintain and if possible increase the Afrikaans offering subject to demand and resources". ${ }^{22}$ In other words, the 2016 Language Policy creates three provisions for language of learning namely; parallel medium, dual medium and single medium. The parallel medium of learning through the use of both English and Afrikaans can only be used "where reasonably practicable and pedagogically sound". All in all, English enjoys preference over Afrikaans. ${ }^{23}$

The High Court dismissed the applicant's application on the basis that the University's obligations, under section 29(2) of the Constitution, only allow the provisions of Afrikaans education where it is reasonably practicable to do so. ${ }^{24}$ The Court further held that to determine whether it is reasonably practicable to provide education in one's official language of choice, the State must consider "what is fair, feasible and satisfies the need to remedy the results of past discriminatory laws and practices". 25 According to the Court, reasonably practicable includes the consideration of the availability of resources and other factors. ${ }^{26}$ The Court found that the 2014 Policy was not in line with the Constitution, as it prevented Black students who were not conversant in Afrikaans access to the University. ${ }^{27}$ Finally, the Court held that the 2016 Language Policy was consistent with the Higher Education Language Policy, which inter alia ensures that "that the existing languages of instruction do not serve as a barrier to access and success". 28 Unsatisfied with the High Court judgement, the applicants appealed to the Constitutional Court.

\footnotetext{
18 Para 19.

19 Para 68.

20 Para 86.

21 Para 53.

22 Para 52.

23 Para 60.

24 Para 19

25 Para 19.

26 Para 20.

27 Para 50.

28 Para 6.
} 


\section{The case before the Constitutional Court}

The majority judgment dismissed the application for leave to appeal. Mogoeng CJ and Froneman J, both wrote separate judgments agreeing with the majority judgment. In the Constitutional Court, the applicants sought an order setting aside the 2016 Language Policy on the grounds that it violated sections 29(2), 6(2), ${ }^{29} 9$ and 6(4) ${ }^{30}$ of the Constitution. The central issue that had to be decided by the Court was whether the University had "sufficiently justified the diminished role for Afrikaans in the 2016 Language Policy, as issued, and not as applied"? ${ }^{31}$

To advance their case, the applicants asserted that, under the 2016 Language Policy, they inter alia foresaw the weakening and the loss of primacy of Afrikaans at the University. The Court rejected this submission on the basis that "the process for adopting the 2016 [Language] Policy was thorough, exhaustive, inclusive and properly deliberated". 32 The applicants' primary contention was that, under section 29 (2) of the Constitution, they had a right to receive tertiary tuition in Afrikaans. ${ }^{33}$

In answering the question on whether the University had sufficiently justified the diminished role of Afrikaans, the Constitutional Court first addressed the applicants' contention that they had a right to receive tertiary education in Afrikaans. The applicants contented that section 29(2) of the Constitution allows for an enforceable right against the state to provide education in the language of their choice. In addressing this, the Court highlighted two aspects about the right to language namely;

“... [R]espect for language preference, where appropriate and reasonable, entails no special concession or privileged treatment. It flows from fundamental rights and values. It is an embodiment of the right to be treated equally and without discrimination, which inheres in everyone. It requires no special pleading for its recognition." 34

29 Gelyke Kanse $v$ Chairperson of the Senate of the University of Stellenbosch 2019 (12) BCLR 1479 (CC). Recognising the historically diminished use and status of the indigenous languages of our people, the state must take practical and positive measures to elevate the status and advance the use of these languages.

30 The national government and provincial governments, by legislative and other measures, must regulate and monitor their use of official languages. Without detracting from the provisions of subsection (2), all official languages must enjoy parity of esteem and must be treated equitably.

31 Para 19.

32 The Court rejected evidence by the applicants that the 2016 Policy was being implemented in a manner that warranted fear of side-lining Afrikaans. Moreover, it held that "the process for adopting the 2016 Policy was thorough, exhaustive, inclusive and properly deliberated". See Gelyke Kanse $v$ Chairperson of the Senate of the University of Stellenbosch supra para 17.

33 Para 20.

34 Para 21. 
Second, it is established in international human rights law that the way in which that respect is practically realised must depend on what is appropriate and reasonable. Section 29(2) of our Bill of Rights recognises this. It accords the right to receive education in public educational institutions in a language of choice "where that education is reasonably practicable". In this, the Constitution accords with international instruments" (footnotes omitted). ${ }^{35}$

In light of the above, the Court highlighted that the test for determining "reasonable practicability" in ascertaining whether one may receive an education in his/her mother tongue language is "synonymous with the test of "appropriate justification" for cutting it back, once afforded". 36 These tests in essence deal with the duty to take positive measures to provide for the right to receive an education in ones' language and a negative duty not to take away the right that is already being provided. As was correctly highlighted in Head of Department: Mpumalanga Department of Education v Hoërskool Ermelo that:

"[T]he reasonableness standard built into section 29(2)(a) imposes a contextsensitive understanding of each claim for education in a language of choice. An important consideration will always be whether the state has taken reasonable and positive measures to make the right to ... education increasingly available and accessible to everyone in a language of choice. It must follow that when a learner already enjoys the benefit of being taught in an official language of choice the state bears the negative duty not to take away or diminish the right without appropriate justification". 37

"The second part of section 29(2) of the Constitution points to the manner in which the state must ensure effective access to and implementation of the right to be taught in the language of one's choice. It is an injunction on the state to consider all reasonable educational alternatives which are not limited to, but include, single medium institutions. In resorting to an option, such as a single or parallel or dual medium of instruction, the state must take into account what is fair, feasible and satisfies the need to remedy the results of past racially discriminatory laws and practices." 38

It follows from the above reasoning that the State is constitutionally mandated to create an environment in which students or learners are able to receive an education in their mother tongue language, provided that it is reasonably practicable to do so. Where a student is already receiving education in their mother tongue language, such as studying in Afrikaans under the 2014 Language Policy, the State cannot interfere with the enjoyment of such a right unless there is an appropriate justification.

Given the previous deliberation on the tests to determine practicably, the applicants presented new proposition which sought to "differentiate between the two tests". 39 They argued that "once the right had been

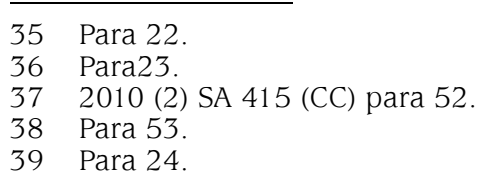


afforded, "appropriate justification" was harder to surmount". ${ }^{40}$ Relying on the High Court, and other similar cases, ${ }^{41}$ the Court rejected this contention on the basis that the decision in Head of Department: Mpumalanga Department of Education v Hoërskool Ermelo "did not create two separate standards". 42 Determined to advance their cause, on the current scope and content of section 29(2) of the Constitution, the applicants developed their section 29(2) of the Constitution argument and included sections 6(2) and (4) of the Constitution. The aforesaid constitutional provisions outline the following, respectively:

"Recognising the historically diminished use and status of the indigenous languages of our people, the state must take practical and positive measures to elevate the status and advance the use of these languages." 43

"The national government and provincial governments, by legislative and other measures, must regulate and monitor their use of official languages. Without detracting from the provisions of subsection (2), all official languages must enjoy parity of esteem and must be treated equitably." 44

In light of the aforesaid constitutional obligations, the applicants submitted that the 2016 Language Policy lacked "meaningful guidelines... directly discriminates against Afrikaans-speaking students, and diminishes Afrikaans tuition at the University in a way not justified on any basis". ${ }^{45}$ In response to the applicant's submission, the Court agreed with the applicant's contention that reasonable practicability has to be looked at objectively, including taking a particular approach based on the available evidence. ${ }^{46}$ The Court nonetheless indicated that the evidence was, in many respects, against the applicants. In the Court's words:

"The evidence shows that, near-universally, brown and white-Afrikaansspeaking first-year entrants to the University are able to be taught in English. Conversely, though most entrants are able to receive tuition in Afrikaans, a significant minority cannot." 47

“... First, most black (in contradistinction to brown) new entrants to the University are not conversant enough to be able to receive tuition in Afrikaans. Second, seen as a bloc, the new entrants for whom Afrikaans is an obstruction are not brown or white, but overwhelmingly black." 48

In light of the aforesaid evidence, the Constitutional Court found that the "uneasy truth" was that the "primacy of Afrikaans under the 2014

40 Para 24.

41 Gelyke Kanse vs Chairman of the Senate of the Stellenbosch University Supra paras 85-6. See also AfriForum v Chairperson of the Council of the University of Pretoria 2017 JDR 0150 (GP) para 54.

42 Para 24.

43 S 6(2) of the Constitution of the Republic of South Africa, 1996.

44 S 6(4) of the Constitution of the Republic of South Africa, 1996.

45 Para 25.

46 Para 26.

47 Para 26.

48 Para 27. 
Language Policy created an exclusionary hurdle for specifically black students studying at Stellenbosch". ${ }^{49}$ The Court inter alia highlighted that the evidence presented before it by the University, regarding the 2014 Language Policy, "made black students not conversant in Afrikaans feel marginalised, excluded and stigmatised". 50 All in all, black students felt that they were not a part of the institution in various respects, as they were effectively barred from receiving an education by the language barrier and socially excluded from other campus social events which were held in Afrikaans. The applicants did not dispute these facts. ${ }^{51}$

The applicants further urged the University to offer tuition in both Afrikaans and English for all undergraduate studies. In response to this, the University agreed that the idea was feasible. However, the University asked whether "it [was] reasonably practicable" to do so in the present circumstance. $^{52}$ The University answered this question in the negative on the basis that:

“... that the cost of immediately changing to fully parallel medium tuition would total about R640 million in infrastructure (including additional classrooms), plus about R78 million each year thereafter for additional personnel costs. This would entail a $20 \%$ increase in fees, an additional R8 100 on top of the approximately R40 000 per year students on average pay now. Reasonably practicable? The University said No." 53

The aforesaid information was not well received by the applicants. Instead, they contended that the cost issues did not form part of the processes that led to the adoption of the 2016 Language Policy. ${ }^{54}$ The Court dismissed this claim and indicated that the cost factor was an unavoidable issue in any operations of the university business. ${ }^{55}$ According to the Court, it was well within the rights of the University to show the monetary factor in defending its 2016 Language Policy and to demonstrate/illustrate that providing tuition in both Afrikaans and English would be too expensive. ${ }^{56}$ The applicants were of the view that funds could be sourced elsewhere, such as from the wealthy alumni of the University who were against the "diminishing the place of Afrikaans". 57 The Court highlighted that the inquiry was not whether the University could source funds elsewhere to sustain both Afrikaans and English, but whether it was practicably reasonable to do. ${ }^{58}$

In response to the main issue on whether the University had "sufficiently justified the diminished role for Afrikaans in the 2016

49 Para 28

50 Para 28.

51 Para 29.

52 Para 31.

53 Para 31.

54 Para 32.

55 Para 33.

56 Para 33.

57 Para 34.

58 Para 34. 
Language Policy", the Court said that the implementation of the 2016 Language Policy was "to facilitate equitable access to its campus and to its teaching and learning opportunities by black students who are not conversant in Afrikaans". 59 The Court, through reliance on its earlier decisions ${ }^{60}$, further found that the University's processes properly considered factors such as "racial equity, access and inclusiveness" in arriving to the decision not to inter alia make Afrikaans a primary language of learning. ${ }^{61}$ Consequently, the Court found it difficult to overturn the Universities' 2016 Language Policy, because the evidence presented before it was clear in that "it was not reasonably practicable to introduce full parallel medium undergraduate teaching in order to avoid some diminution of Afrikaans". 62

The applicants asked the Court whether it was possible, under section 29(2) of the Constitution, to take away a right that is already offered to in order to create access for those who are not conversant with Afrikaans because the University regards the cost of retaining such language as being too high. ${ }^{63}$ The Court answered this in the affirmative on the basis that, unlike in the University of Free State, in this case Afrikaans was not abolished but reduced from its primacy. ${ }^{64}$ According to the Court, this was constitutionally justified. ${ }^{65}$

The applicants had also argued that, since Afrikaans was an indigenous language, it had to be protected as an official language, and had to be treated equally to other languages. ${ }^{66}$ As a result, the applicants asked the court to set aside the 2016 Language Policy on the basis that it was bringing an end of Afrikaans as a language of tertiary instruction. ${ }^{67}$ While counsel's plea on behalf of indigenous languages other than Afrikaans may have seemed opportunistic, the dire entreaty compels reflection. The Court accepted that approving the University's 2016 Language Policy as constitutionally compatible with section 29(2) of the Constitution has consequences. According to the Court, such consequences include the seemingly global unfavourable approach to minority languages. Despite this cautious approach, the Court indicated that the "... dilemmas the global march of English poses is not the question before [it] ..." ${ }^{68}$ Therefore, this was the end of the matter.

59 Para 36.

60 See University of the Free State $v$ Afriforum 20171 All SA 79 (SCA) para 27; Head of Department: Mpumalanga Department of Education $v$ Hoërskool Ermelo 20102 SA 415 paras 45-7 and 51-3; AfriForum $v$ University of the Free State supra paras 53-4.

61 Para 36.

62 Para 45.

63 Para 38.

64 Para 40.

65 Para 41.

66 Para 46.

67 Para 47

68 Para 49. 
In a separate but concurring judgment, Mogoeng $\mathrm{J}$ agreed that the 2014 Language Policy was not practicably reasonable as it prevented many people from accessing higher education. ${ }^{69}$ He further acknowledged that, despite the controversies that surrounded the use of Afrikaans during apartheid, these "did not at all affect its original African DNA". 70 Interestingly, Mogoeng CJ further appealed to the private sector in the spirit of brotherhood to help in preserving Afrikaans and to "develop other indigenous languages, as essential tools for knowledge impartation and comprehension". ${ }^{71}$ These development could take place through the establishment of private institutions of learning. However, Mogoeng J warned that such private institutions should "not be driven by any sinister agenda to discriminate against others on any unconstitutional basis". 72

Ultimately, Froneman J also provided a separate but concurring decision. He nonetheless seemed to be concerned about the fact that English was being elevated and given dominance from primary school up to tertiary. ${ }^{73}$ In his own words, "... it seems strange for this Court, the ultimate protector of minority language rights under the Constitution, to give its blessing to this result". ${ }^{74}$ Froneman's J further concern was that the elevation of English ahead of other languages had dire repercussions. According to him, those who come from the poorest of the poor who are "mainly black and brown people" who "attend under-resourced and poorly staffed schools in rural and marginalised urban communities, will suffer most" as their already chosen language of instruction is English. ${ }^{75}$ This is further worsen by the fact that they do not only "receive inadequate mother-tongue education when they start their education, but the education that they receive in English is also often of a poor quality". 76

Froneman J highlighted that the evidence the Court showed that Afrikaans is a home language of many of brown people in the Western Cape and Northern Cape. ${ }^{77}$ Additionally, it indicated that they are "predominantly working-class people and that many of them are not proficient in English". ${ }^{78}$ The evidence further indicated that only a few brown people who make it to tertiary because of poverty related reasons. According to the judge, the unfortunate reality is that for those who may happen to get to tertiary and receive education in their mother tongue language, Stellenbosch University would be their destination. However, given the recent developments, when they get there, they will realise that

69 Para 60

70 Para 61.

71 Para 62.

72 Para 62.

73 Para 75.

74 Para 75.

75 Para 77

76 Para 77.

77 Para 78.

78 Para 78. 
their mother tongue langue is not offered and "if they are [to] be accommodated, they need to grow out of poverty and learn English fast" 79 Froneman $\mathrm{J}$ stated that this problem applies to other marginalised and vulnerable poor people whose home language is not English. ${ }^{80}$ Froneman J admitted that this was not a matter to be taken lightly. He categorically states that "[s]uccessful mother-tongue or vernacular language education is not easily attained, but it can be done." 81

\section{Analysis of judgments}

In our view, the Constitutional Court in the present matter was not much placed in a difficult position as it had already dealt with cases of similar nature before. ${ }^{82}$ In addition, it had the benefit of both the High Court ${ }^{83}$ and the Supreme Court of Appeal decisions ${ }^{84}$ as a foundation to start with. This is something that the Court itself acknowledged. ${ }^{85}$

We are further in agreement with the Court that this was a different case from that of the University of Free State, as Afrikaans was not abolished but preserved to be only applied subject to demand and availability of resources. ${ }^{86}$ Therefore, in our view the applicants were incorrect to argue that “... upholding the University's policy change ... would signal the end of Afrikaans as a language of tertiary instruction". 87

In dealing with the applicant's argument that "once the right had been afforded, "appropriate justification" was harder to surmount", 88 we submit that the Court correctly rejected this argument. It appropriately relied on its earlier decisions on the scope and content of section 29(2) of the Constitution. The Court appropriately applied the test of determining whether it was "reasonable practicability" in ascertaining whether one may receive an education in one's mother tongue language. It considered the evidence brought before it by the university, such as the R640 million cost of infrastructure if both Afrikaans and English were to be fully implemented as parallel mediums of instruction. Additionally, there would be a further estimated R78 million annually for additional personnel costs, including a $20 \%$ increase in fees (about 48100.00 per annum). ${ }^{89}$ Based on this, the Court found that it was within the

\footnotetext{
79 Para 78.

80 Para 79.

81 Para 91.

82 Head of Department: Mpumalanga Department of Education $v$ Hoërskool Ermelo supra para 1.

83 Gelyke Kanse vs Chairman of the Senate of the Stellenbosch University supra.

84 AfriForum $v$ University of the Free State supra.

85 Gelyke Kanse $v$ Chairperson of the Senate of the University of Stellenbosch supra paras 59 and 64.

86 Para 6.

87 Para 47.

88 Para 24.

89 Para 31.
} 
University's rights to raise/highlight the cost implications of the applicants' proposals. Importantly, the Court found that the University took into account relevant factors and therefore complied with the "reasonably practicable" test in favouring English over Afrikaans. ${ }^{90}$ The Court further concluded that the University's decision to introduce the 2016 Language Policy to "downward Afrikaans without by any means eliminating it" was inter alia driven by "equitable access to its campus and to its teaching and learning opportunities by Black students who are not conversant in Afrikaans". "We have reservations with the preceding statement and we address this below.

We also note, with admiration the approach taken by the Court to rely on its previous decisions regarding the scope and content of section 29(2) of the Constitution. This involves both a factual and normative (constitutional) element. ${ }^{92}$ The Court reiterated that reasonable practicability is to be looked at objectively and requires an approach founded in evidence. It was on this basis that the Court found that the evidence presented before it showed that it was not reasonably practicable to keep Afrikaans as one of the languages of primary tuition, because of the inevitable cost implications and the inclination to increase access to University for those who are not conversant in Afrikaans.

Whilst we accept that Afrikaans was downgraded in order to facilitate access to those who were not conversant in it, we are of the view that this factor should have been looked at a different angle. We are also in agreement with the separate but concurring decision of Froneman J, who illuminated the fact that the global community has adopted and accepted English as a global language and highlighted that evidence showed that Afrikaans is a home language of many of brown people in the Western Cape and Northern Cape. ${ }^{93}$ In fact 49.6 per cent of people speak Afrikaans in the Western Cape. ${ }^{94}$ In our view, this is a matter that the Court ought to have not taken lightly. The poor and marginalised Afrikaans speaking people, who are mostly conversant in their own language, will miss the opportunity to receive education in their mother tongue language. According to the judge:

"Now when they arrive at Stellenbosch, they will find that their choice of medium of instruction is not as comprehensive as those more privileged students who choose English. The grim message that seems to be sent to this segment of extremely marginalised brown people, is that, if they are be accommodated, they need to grow out of poverty and learn English fast." 95

\footnotetext{
$90 \quad$ Para 36.

91 Para 36

92 Para 26.

93 Para 78.

94 Statistics South Africa "Census 2011 Provincial Profile: Western Cape" (2011) http://www.statssa.gov.za/publications/Report-03-01-70/Report-0301-702011.pdf (accessed 2020-02-17).

95 Gelyke Kanse $v$ Chairperson of the Senate of the University of Stellenbosch supra para 78.
} 
This is an unfortunate reality faced by many other poor and marginalised communities. For example, Walter Sisulu University is located in Mthatha and most of its students come from surrounding areas where the spoken language is IsiXhosa. However, when they get to University, they are suddenly expected to master the English language.

It is unmistakable that the essence of the judgment is to shed light on the importance of language as a tool for sustaining relationships through communication, cultural identity and transmission. Most importantly, the judgment illustrates the significance of safeguarding and preserving indigenous languages, which have been and continue to be under threat, having due regard for South Africa's historical context. The practicability of the judgment is not straightforward. That is to say, historically, the country's black and brown majority has been subjected to protracted marginalisation and relegated to menial roles by virtue of their skin colour, traditions and cultural practices. This relegation/ assignment of inferiority was heightened by the institution of English and Afrikaans as the languages of instruction.

To remedy this historical error, there must be a vigorous promotion of the languages that were historically denigrated, and these unjustly deprecated languages must be given a platform to flourish. A pivotal question to ask is: how does one elevate or restore a historically disadvantaged language, for purposes of preserving that language, without undermining historically dominant languages that are protected by the Constitution? The process of preserving historically disadvantaged languages, will inevitably lead to increased resistance from the native speakers of dominant languages, who would understandably seek to preserve their own languages. This reality requires a balanced equilibrium for the protection of languages in their entirety. There is a need to find sustainable solutions to preserve and use historically disadvantaged languages.

In exploring mechanisms aimed at preserving languages, teaching may be seen as a tool to do so. The silent reality is that when institutions such as Sol-Tech ${ }^{96}$ emerge, with the intention of using Afrikaans as a teaching medium of instruction, they run the risk of being perceived as discriminatory and intent on excluding other individuals. The arguments underlying such a risk should not be undermined, considering South Africa's history of systematic and institutionalised exclusion. Having said that, would the same sentiment be upheld, if for example, an institution emerged with the intention of using Sotho, Sesotho and Tswana as a teaching medium of instruction?

The approach of this analysis takes an Afrocentric perspective in an attempt to emphasise the importance of academic freedom. Generally, mother tongue, native or first language, is a language a person learns

96 A private vocational training institution founded on Christian values and uses Afrikaans as a medium of instruction. See https://sol-tech.co.za/ (accessed 2020-03-07). 
from birth. According to Yadav, the ability to acquire a language is biologically linked to age, therefore becoming the basis for social identity and the medium of learning in school and society. ${ }^{97}$

The usage of mother tongue language in education has the ability to increase self-confidence in students, enhance their thinking skills and enable students to exercise their freedom of speech. ${ }^{98}$ In a diverse society and multilingual context, one of the main issues that surround teaching and learning in one's native language is discrimination. In such instances, as stated by the High Court, "it will always be arguable that one or other language is subordinated relative to others". 99 In addressing such issues, and emphasised by the UNESCO's 1974 report, the elimination of discrimination between majority and minority students "is to use their mother tongue in education within a bilingual education model". 100

In a study conducted by Ozfidan, the results reflected that the opportunity to use one's own language was vital for minority groups. ${ }^{101}$ This is because such usage protects one's culture and identity as well as encourages participation in public life. In light of these results, language is therefore a crucial factor for the academic achievement of (minority) people. ${ }^{102}$

Taking into account the history of South Africa and the need to exercise caution, as articulated by Froneman J, perhaps the approach on language in South Africa's educational system should generally attempt to defy Eurocentric ${ }^{103}$ methods of education and promote Afrocentricity, ${ }^{104}$ since it (Eurocentric methods) weakens or undermines indigenous languages, knowledge and experience.

Two issues can be deduced in the case discussed.

i English vs Afrikaans: on a global scale, English is a widely spoken language and its growth can be seen in two contexts: (a) the growth of England as an imperial power; and (b) the spread of English as an imperial language. ${ }^{05}$ Afrikaans on the other hand, is a language that

97 See Yadav "Role of Mother Tongue in Second Language Learning" 1 (2014) IJR 527-576.

98 Ozfidan "Right of Knowing and Using Mother Tongue: A Mixed Method Study" 2010 English Language Teaching 17.

99 Gelyke Kanse vs Chairman of the Senate of the Stellenbosch University para 13.

100 Ozfidan 2017 English Language Teaching 21.

101 Ozfidan 2017 English Language Teaching 21.

102 Ozfidan 2017 English Language Teaching 21.

103 Eurocentrism may be understood as the universal interpretation centred on Europe or the tendency of interpreting the world in terms of European or Anglo-American values and experiences. See Merriam Webster dictionary.

104 Afrocentricity on the other hand, is the thought process and action centred on African interest, values and perspectives. See Asante, Afrocentricity: The theory of social change (2001) 3 .

105 Cummins and Davison, International Handbook of English Language Teaching (2007) 13. 
many deem to be an African language. In light of this, the overwhelming use of English in society erodes indigenous language, and in general, this includes Afrikaans. In this instance, as an African language, and in the context of Afrocentricity, the use of Afrikaans as an indigenous language ought to be promoted.

ii Afrikaans vs other official South African languages. The playing field is skewed when one language is positioned and postured as pre-eminent and above all others. Despite Afrikaans having African origins, the language was developed during the colonial era in Southern Africa. In this context, the promotion of this language undermined existing indigenous languages at the time. With this in mind, and with reference to this case, it was crucial for the courts to determine what is in the best interest of black students who are not proficient in Afrikaans. Ideally, in an attempt to promote Afrocentricity and where it is reasonably practicable, black students should receive education in their language of choice (for instance, isiXhosa a dominant language in the region of the SU, and ideally, given availability of resources, it would be logical to provide tuition in isiXhosa).

One must realise that the persistent use of English language and the insufficient provisions on the usage of native languages in the South African education system gradually erodes native languages. To further buttress this point, Cameroon J (as he was then) has asserted that "All of our indigenous languages are under threat from this monster we are talking, the language that is the primary language of business and communication." 106

The advancement of a language that is not indigenous to Africa was done at the expense of African languages. The irrefutable consequence of colonialism in Africa, through the introduction and facilitation of the colonial education system, has led to European or colonial languages becoming official languages of the African continent. ${ }^{107}$ This has led to a hierarchy of languages, in terms of which the colonisers' language has been globally accepted and perceived as prestigious and dominate ${ }^{108}$ in both private and public sectors. In our view, to remedy the injustices of colonialism, African States should obliterate the colonial legacy, particularly the education system that was imposed by the colonisers in an effort to weaken African languages.

It is evident from this case that the use of Afrikaans as a medium of instruction results in the marginalisation of Black students who are not proficient in Afrikaans. In the judgment, it was articulated that “... [b]lack and brown people from the lowest socio-economic rung, who attend under resourced and poorly staffed schools in rural and marginalised

106702 "All of our indigenous languages are under threat from English-Justice Cameron" 702 (2019-10-11) http://www.702.co.za/articles/363503/all-ofour-indigenous-languages-are-under-threat-from-english-justice-cameron (accessed 2019-12-26).

107 For example English is one of the official languages in South Africa, Kenya, Nigeria, Ghana, and Zimbabwe.

108 Tsung Languages Power and Hierarchy: Multilingual Education in China (2014) 6-7. 
urban communities, will suffer most from effectively having their language of instruction being limited to English". Efforts have to be made by public institutions, supported by the state, to find ways in which tertiary education could be provided in a language of a student's preference. As mentioned above in the judgments, it is the duty of the State to ensure that education is provided in a language one prefers, however, the realisation of this imperative is subject to reasonable practicability deduced in section 29(2) of the Constitution. In other words, considering that students in underprivileged societies are neither proficient in English or Afrikaans, language as a medium of instruction should therefore not be limited to English or Afrikaans. In essence, to address the "flood tide of English" as a threat to minority languages, decolonisation through language is essential because it has the capability of enhancing knowledge production and social transformation. ${ }^{109}$ Lessons can be learned from institutions such as UNISA, which conferred a PhD in Setswana ${ }^{110}$ and Rhodes University which conferred its first $\mathrm{PhD}$ in isiXhosa. 111

The judgments attempted to facilitate access to education. It was held that, there is no ideal solution when addressing the Constitutional principles raised regarding the manner in which the University should accommodate - (a) the rights of the Afrikaans-speaking students to their language and culture; (b) the promotion of multilingualism; and (c) the rights of primarily Black (African) people who are not conversant in Afrikaans to access a tertiary education at the University. Furthermore, in the absence of a language policy that assigns equal weight to all eleven of the official languages in every subject of the curriculum, it will always be arguable that one or other language would be subordinated relative to others. Importantly, the reality of limited resources entails that any recognition of a linguistic or cultural right may be to the detriment of a competing and arguably more deserving right. To support this, Stoop pointed out that "the state has two obligations ...: to ensure that the necessary attention and care are given to this right as well as to demonstrate that it is acting reasonably and practically in providing for the right to receive education in one's preferred language". 12

In our view, the issue of the use of indigenous languages at institutions of higher learning requires a concerted effort from all the stakeholders. The emergence of private institutions to offer tuition in Afrikaans only

109 See Fataar "Decolonising Education in South Africa: Perspectives and Debates" 2018 Educational Research for Social Change.

110 Power 98.7 "Meet Unisa's first Setswana PhD graduate” (2019-11-25) https:/ /www.power987.co.za/news/unisa-confers-first-phd-setswanal (accessed 2019-12-30).

111 Skade "Meet the man who wrote Rhodes University's first isiXhosa PhD thesis" Rhodes University (2017) https://www.ru.ac.za/graduationgateway/ graduationnews/articles2017/meetthemanwhowroterhodesuniversitysfirst isixhosaphdthesis.html (accessed 2019-12-30).

112 See Stoop, "Children's rights to mother-tongue education in a multilingual world: a comparative analysis between South African and Germany" 2017 PELJ 1-35. 
will not solve the politics surrounding languages. Instead, the State has to be the driver of this transformative constitutionalism imperative ${ }^{113}$ at public institutions. The notion of transformation cannot be ignored when interpreting the Constitution. Transformative constitutionalism is derived from the Constitution and is an indispensable element of legal and constitutional developments. ${ }^{114}$ Given that there is no universal definition of transformative constitutionalism, Rapatsa provides three ways in which transformative constitutionalism is essential: it gives true meaning to democracy, it enriches human rights discourse and remodels social welfare. ${ }^{115}$ Rapatsa's understanding of transformative constitutionalism to a large extent resonates with that of Klare. According to Klare, transformative constitutionalism means:

“... a long term project of constitutional enactment, interpretation and enforcement committed (not in isolation, of course, but in a historical context of conducive political developments) to transforming a country's political and social institutions and power relationships in a democratic, participatory, and egalitarian direction. Transformative constitutionalism connotes an enterprise of inducing large-scale social change through nonviolent political processes grounded in law ..."116

Indeed, the reconstruction of the society is not only the duty of the state or the courts alone, but that of all South Africans, united in their diversity, through meaningful engagement ${ }^{117}$ with the affected groups in order to find lasting solutions. 18 An appreciation of transformative constitutionalism requires one to recognise that the apartheid system marginalised, exploited and oppressed people of African descent. Post1994, a non-racial multi-lingual South Africa was brought with the political system transitioning to majority rule and democracy and constitutional supremacy. ${ }^{119}$ Simply put, the essence of the Constitution is to recognise past injustices and provide guidance aimed at providing a better future for all. This, then, becomes the core idea of transformative constitutionalism. According to Langa, this core idea requires change, therefore, relevant questions such as "how much [should/can] we change? How does the society on the other side of the bridge differ from where we stand today?" (emphasis added). ${ }^{120}$ In answering this, Langa pointed out

113 See inter alia the Preamble to the Constitution of the Republic of South Africa, 1996.

114 Rapatsa, Transformative Constitutionalism in South Africa: 20 Years of Democracy, MJSS 2014 (5) 889.

115 Rapatsa, Transformative Constitutionalism in South Africa: 20 Years of Democracy, MJSS 2014 (5) 887.

116 Klare "Legal Culture and Transformative Constitutionalism" 1998 SAJHR 150-151.

117 Occupiers of 51 Olivia Road, Berea Township and 197 Main Street Johannesburg $v$ City of Johannesburg 20083 SA 208 (CC); Residents of Joe Slovo Community, Western Cape v Thubelisha Homes 2009 9 BCLR 847 (CC).

118 Mokgokong and Phooko "What has the Constitutional Curt Given us? Afriforum v University of the Free State 2018 (4) BCLR 387 2019" Obiter 239.

119 Pieterse "What do we mean when we talk about transformative constitutionalism" 2005 (20) SAPR/PL 157.

120 Langa "Transformative Constitutionalism" 2006 (3) SLR 352. 
two important aspects: (1) that substantive equality has to be the basis of the new society; ${ }^{121}$ and (2) the transformation of the legal culture. ${ }^{122}$ In an effort to safeguard the principles of constitutional democracy, Rapatsa asserts that:

"legal culture concerns the broader perspective of how the Constitution is interpreted, how the law is applied and practiced, and how it influences developments in the country. It is about the nature of characteristic legal values, expressions and arguments by legal practitioners, and those in other disciplines." 123

Substantive equality, on the other hand, is a transformative approach that calls for laws or policies not to buttress or enhance the inferiority of groups that are already suffering social, political or economic disadvantage, through the treatment of individuals as substantive equals. ${ }^{124}$ As a social and economic revolution, transformation calls for levelling the economic playing fields which the apartheid system significantly tilted. This transformative approach will, therefore, fulfil social-economic rights and also provide access to education and opportunities. ${ }^{125}$

In achieving substantive equality, transformation ought to be perceived as a permanent ideal and not a short-term concept that concludes when everyone has equal access to resources and basic services and when those in the legal fraternity embrace a culture of justification. ${ }^{126}$ In other words, transformative constitutionalism calls for social change through nonviolent processes grounded in law. ${ }^{127}$

Against the above literature, the University in this case appears to have embraced the notion of transformative constitutionalism when they decided to adopt the 2016 Language Policy, which diminished Afrikaans in order to improve access to the institution for others who are not conversant in Afrikaans. Unfortunately in the process, an indigenous language was affected at the expense of the English language.

Overall, we submit that where South African public tertiary institutions are able to teach in all languages protected by the Constitution, respect for cultural diversity will be enhanced including social cohesion.

121 Langa "Transformative Constitutionalism" 2006 (3) SLR 352.

122 Langa "Transformative Constitutionalism" 2006 (3) SLL 353.

123 Rapatsa "Transformative Constitutionalism in South Africa: 20 Years of Democracy” 2014 (5) MJSS 889.

124 Smith "Equality constitutional adjudication in South Africa" (2014) 14 AHRLJ 613.

125 Langa "Transformative Constitutionalism" 2006 (3) SLR 352.

126 Langa, "Transformative Constitutionalism” 2006 (3) SLR 354.

127 Rapatsa "Transformative Constitutionalism in South Africa: 20 Years of Democracy” MJSS 2014 (5) 888. 


\section{What have the other courts given us?}

This section discusses various decisions that have been made by the courts in attempt to resolve the issue of the use of certain languages over other languages within the education sector and before the courts.

\section{Afriforum v University of Pretoria ${ }^{128}$}

In 2016, the University of Pretoria, through the decision of Senate and Council, implemented a new language policy, which provided that English shall be the main language of learning and teaching. From the University's perspective, the new language policy was "aimed at removing segregation and facilitating social cohesion". ${ }^{29}$ Afriforum sought to review and set aside the decision, arguing that the decision contravened Section 29(2) of the Constitution and further arguing that "it is reasonably practicable to offer tuition in Afrikaans". 130

Language is more than a mere tool of communication, it plays a crucial role in human development and the construction of human identity. The unfortunate disadvantage of language versatility is that, as demonstrated by history, language can be used by the so called powerful elites "as a tool of domination, of subjugation and of exclusion". 131

Section 29(2) of the Constitution provides that, in part, "everyone has the right to receive education in the official language or languages of their choice in public educational institutions where that education is reasonably practicable". In addressing this issue, the Court referred to the Hoërskool Ermelo case. The case concerned the right to be taught in one's official language of choice and addressing whether or not the Head of Department had the power to withdraw the function of the School Governing Body to determine the language policy of the school. In part and with reference to Section 29(2) of the Constitution, the Constitutional Court held that:

"The provision is made up of two distinct but mutually reinforcing parts. The first part places an obvious premium on receiving education in a public school in a language of choice ... The second part of section 29(2) of the Constitution points to the manner in which the state must ensure effective access to and implementation of the right to be taught in the language of one's choice.' ${ }^{132}$ With reference to the first part, the Constitutional Court held that the right to be taught in one's language of choice, however, the element of choice is available only when it is reasonably practicable. When it is reasonably practicable to receive tuition in a language of one's choice will depend on all the relevant circumstances of each particular case. In short, the reasonableness standard built into section 29(2)(a) imposes a context-

128 Afriforum and Another $v$ Chairperson of the Council of the University of Pretoria and Others [2017] 1 All SA 832 (GP).

129 Para 35.

130 Para 3 and 25.

131 Para 1 and 2.

132 Para 52 and 53. 
sensitive understanding of each claim for education in a language of choice."133

In its decision, the Court held that 'the new policy cannot be discriminatory simply because it ceases to offer Afrikaans as a language choice of instruction. The court in this regard was, to a certain extent, applying the test for unfair discrimination as laid down in Harksen $v$ Lane. ${ }^{134}$ In order to determine the presence or otherwise of unfair discrimination one must ask (1) Does the provision differentiate between groups? If yes, then the next question is (2) whether there is a rational connection between the differentiation and a legitimate governmental purpose it is designed to achieve? ${ }^{135}$ Is the purpose consistent with the underlying values protected by the equality clause? Is there no evidence of arbitrariness or manifestations of "naked preferences" without legitimate government purpose? If yes, then it will be evident that it does not amount to a breach of equality but may nonetheless constitute unfair discrimination. ${ }^{136}$ If one has regard to the overall effect of the policy decision to make English the sole language of instruction ... then it may well constitute some levelling of the playing fields but in a constructive and forward-looking manner. ${ }^{137}$ In light of this, one may ask whether or not we can talk about "levelling the playing field" when it is one colonial language (English) dominating indigenous languages? Furthermore, the Court held that the language policy was consistent with Section 29(2) of the Constitution and it (language policy) calls for the advancement of social cohesion. 138

\section{Nkosi v Mrs Vermark and Durban High School Governing Body 139}

The main issue before the Court in this case was whether the Afrikaans language policy adopted by the respondents during the course of 2007 unfairly discriminated against the complainants who are zulu speaking. ${ }^{140}$ The complainants inter alia argued that the effect of the policy "would be that proficiency would not be reached by such a learner in his or her home language". ${ }^{141}$ They further contended that the failure to receive education in their mother tongue

"at the correct level would lead to an alienation from one's culture, and a tendency to uphold other people's culture at the expense of one's own. In other words, the school used English as a primary mode of instructions. ${ }^{142}$ Other languages such as Isizulu were treated as additional languages. ${ }^{143}$ In

133 Para 52.

1341998 (1) SA 300 (CC).

135 Harksen $v$ Lane para 42.

136 Harksen $v$ Lane para 43.

137 Harksen $v$ Lane para 51.

138 Harksen $v$ Lane para 73.

139 77/2007 (Equality Court).

140 Para 1.

141 Para 3.

142 Para 3. 
answering the question of whether or not the complainants were unfairly discriminated, the court had regard to the notion of achievement of equality as a "constitutional imperative of the first order". ${ }^{44}$

It further considered the National Language Policy Framework whose aims include the promotion of "equitable use of the official languages at all levels of government and to facilitate equitable access to government services, knowledge and information, to ensure redress for the previously marginalised official indigenous languages", amongst other factors. ${ }^{145}$ Based on these, the court found that the complainants unfairly discriminated against all leaners whose home language was isizulu, by the offering of "Afrikaans as a subject at a higher level than the subject of isizulu". ${ }^{146}$ The Court utilised its ability to apply the Bill of Rights principles by promoting the use of isizulu. The court also stated in passing that the realisation of the ideals contained in the Constitution into reality requires the "the necessary political will and courage by those entrusted with the duty of turning the ideals enshrined in the Constitution into reality to do so". ${ }^{147}$ In other words, the right in the Constitution remain a dream if those who are elected are not taking necessary measures to ensure that other languages are also elevated to the same level as English or Afrikaans.

\title{
$53 S$ v Damani ${ }^{148}$
}

This case concerned the magistrate's discretion to use isiZulu language to conduct the criminal trial. ${ }^{149}$ The accused was convicted of assault with intent to do grievous bodily harm and subsequently sentenced to imprisonment with certain condition. ${ }^{150}$ The case was submitted on automatic review. The reviewing judge inter alia asked what had motivated the magistrate to conduct the entire trial in isizulu. ${ }^{151}$ The response of the magistrate was that it was his decision to conduct the trial in isizulu, because the majority of the people of Mahlabathini are Zulu speaking and that all of the participants in the trial spoke isizulu. ${ }^{152}$ The magistrate further indicated that the Constitution requires the recognition of the equality of all 11 official languages. Following the aforesaid responses from the magistrate, the reviewing presiding officer sought inputs on the matter from the chief magistrate of Pietermaritzburg and thereafter found that "the use of any of the 11 official languages in courts is no doubt a constitutionally noble idea and the measure would go a long way towards realising and facilitating the people's right of access to courts and to justice". ${ }^{153}$ He further stated that

\author{
143 Para 3. \\ 144 Para 7. \\ 145 Para 7.2. \\ 146 Para 11. \\ 147 Para 10. \\ 1482016 (1) SACR 80 (KZP). \\ $149 S v$ Damani para 1. \\ $150 S v$ Damani para 2. \\ $151 S v$ Damani para 3. \\ 152 Sv Damani para 5.
}


"all attempts and efforts that are aimed at elevating, promoting and advancing the status and the use of indigenous languages in courts, particularly the lower courts at this stage, are to be welcomed and encouraged". ${ }^{154}$ However, he warned that such an approach should be taken with extreme caution and in consideration of various factors such as resources and structures that would enable the use of indigenous languages smoothly and expeditiously. ${ }^{155}$ According to him, there was a need for proper planning in this regard. The reviewing judge ultimately certified the proceedings to have been in accordance with justice. ${ }^{156}$

\section{Lourens $v$ Speaker of the National Assembly of Parliament and Others ${ }^{157}$}

The premise of the complainants' case was that national legislation enacted by Parliament was not published in all eleven official languages, "thereby undermining the official status of the official languages (other than English) and effectively elevating English to the status of 'super official language". ${ }^{158}$ The applicants' main argument was that the eleven official languages must always be treated equally. ${ }^{159}$ According to the Court, this raised a question of whether the non-publication of national legislation in all official languages amounted to discrimination. ${ }^{160}$ In addressing this issue, the Court acknowledged "that the non-publication of national legislation in all official languages does indeed amount to discrimination". ${ }^{161}$ However, such discrimination was fair because "the Constitution permits the use by the national government and provincial governments of any particular official languages 'for the purposes of government", provided that they "must use at least two official languages". 162 The Court found that the predominant use of English in parliament was sufficiently explained and acceptable in that all parliamentarians understand English and can effectively participate in the work of Parliament in English something that is not possible with other languages. ${ }^{163}$ Further, the Court found that there was no "constitutional or statutory duty on any of the respondents to publish all national legislation in all official languages, nor to translate all national legislation into all official languages". ${ }^{164}$ This decision was subsequently confirmed by the Supreme Court of Appeal. ${ }^{165}$

153 S v Damani para 20.

$154 S v$ Damani para 20

155 S v Damani para 20.

$156 S v$ Damani para.

1572015 (1) SA 618 (EqC).

158 Lourens $v$ Speaker of the National Assembly of Parliament and Others para 4.

159 Lourens $v$ Speaker of the National Assembly of Parliament and Others para 26

160 Lourens $v$ Speaker of the National Assembly of Parliament and Others para 26.

161 Lourens $v$ Speaker of the National Assembly of Parliament and Others para 27.

162 Lourens $v$ Speaker of the National Assembly of Parliament and Others para para 29

163 Lourens $v$ Speaker of the National Assembly of Parliament and Others para para 30.

164 Lourens $v$ Speaker of the National Assembly of Parliament and Others para para 32 . 
The above decision presents a case wherein it may be justifiable in certain circumstance to use two languages in the exclusion of other for the purposes of conducting the affairs of the government. In other words, if the discrimination serves legitimate governmental purposes, such discrimination or preference of one language over the other would be found to be constitutionally permissible.

\section{$56 S$ v Damoyi ${ }^{166}$}

This case concerned absence of an interpreter who could interpret from English to IsiXhosa for the accused. ${ }^{167}$ Despite several postponements, an interpreter could not be found. However, given the fact that both the Magistrate and the Prosecutor were also Xhosa-speaking, the Magistrate decided that the proceedings continue without an interpreter. The proceedings were recorded in IsiXhosa. ${ }^{168}$ The accused was convicted as charged and sentenced. The matter was later referred to the High Court by way of an automatic review in terms of section 302(1) of the Criminal Procedure Act 51 of 1997.

The approach of the Court is similar to that of the Lourens $v$ Speaker of the National Assembly of Parliament and Others case in that the proceedings were in accordance with justice. However, the Court also cautioned that the issue of use of one's language should be approached in a holistic manner to prevent a situation where it could negatively impact on the administration of justice. ${ }^{169}$ The Court further stated that the correct interpretation of section 35(3) of the Constitution is that an accused does not have the right to have trial conducted in the language of his/her choice, but simply in a language he/she understands, or if this is not practicable, the proceedings may be interpreted into such a language the accused understands. The Court further emphasised that the shortfall of this view is that it does not address "the issue of parity of the use of languages in court proceedings". 170 The Court was acknowledged the sensitivity of the use of languages in court. It said:

"What clearly emerges from the few decisions in which the issue of parity of languages was considered is the divergence in views concerning the use of official languages in court proceedings. The burning issue still is which of the eleven of the official languages should be used as the language of record in court proceedings. The solution to problems such as the one raised in this matter could be the introduction of one language of record in court proceedings. I am of the opinion that the recommendation by Tshabalala, J in $\mathrm{S} \mathrm{V}$ Matomela (supra) is the route to follow, and, in my view, such a course would not only be economical but would be in the best interest of justice. After all English already is a language used in international

165 [2016] 2 All SA 340 (SCA).

166 [2003] JOL 12306 (C).

$167 S v$ Damoyi para 3.

$168 S v$ Damoyi para 3.

$169 S v$ Damoyi para 1.

$170 S v$ Damoyi para 17. 
commerce and international transactions are exclusively concluded in the English language. Although some stakeholders would take it with a pinch of salt, sanity would tip the scale in favour of English as the language of record in court proceedings, particularly in view of its predominance in international politics, commerce and industry." 171

We agree with the judge in that, it is unfortunate that many years into democracy there are still challenges regarding the use of indigenous languages in court. This somehow could be viewed as a lack of commitment from the government to ensure that there are resources to promote all official languages for use in the courts. There is also no clear guidance from the decisions, as each matter is decided based on its own unique circumstances. We, nonetheless, differ with the judge with regards to the nonchalant position that "[a]fter all English already is a language used in international commerce and international transactions are exclusively concluded in the English language". This is incorrect. There are countries, such as Angola and Mozambique, which do not use English as a primary mode of communication and conclude their transactions in other languages.

\section{$57 \quad S$ v Makwanyane and Mchunu ${ }^{172}$}

Section 6(1) of the Constitution outline the official languages of the Republic of South Africa. Notwithstanding debates of the term official in aforementioned section, it is clear that section 6(1), read with section $6(2)$, is a consequence of the recognition of language oppression and appreciation of indigenous languages. To buttress this, the Constitution goes further to provide "the right to receive education in the official language or languages of their choice in public institutions", ${ }^{173}$ the key consideration of course is that provided that it is reasonably practicable. It is insufficient to justify the usage of English and/or Afrikaans as medium of instructions in public institutions on grounds that they are universally recognized, they are languages of conducting business, or simply that government does not have the necessary resources. Where active political will exists, measures and processes will be adopted to ensure that any other language can be conducted in education systems, failure to which, section 29(2) may be fairly limited due to, for example, lack of resources. To emphasis this, in the case of Makwanyane, the Court held that "the limitation of constitutional rights for a purpose that is reasonable and necessary in a democratic society involves the weighing up of competing values, and ultimately an assessment based on proportionality". 174

Acknowledging that section 29(2), in its entirety, is dependent on the element of reasonable practicability, "there is no absolute standard which can be laid down for determining reasonableness and

171 S v Damoyi para 18.

1721995 (6) BCLR 665 (CC).

173 Ibid.

174 Para 104. 
necessity". ${ }^{175}$ Therefore, it is imperative that, in the interpretation of this section 29(2) and acknowledgment of the language oppression in South Africa, different interests have to balanced and scale of language usage tipped. In doing this,

"the relevant considerations will include the nature of the right that is limited, and its importance to an open and democratic society based on freedom and equality; the purpose for which the right is limited and the importance of that purpose to such a society; the extent of the limitation, its efficacy, and particularly where the limitation has to be necessary, whether the desired ends could reasonably be achieved through other means less damaging to the right in question". 176

In other words, the court will consider whether there are any other means that can be used to limit the affected right without completely taking it away.

\section{Afriforum v UNISA case ${ }^{177}$}

The University of South Africa (UNISA) adopted a revised language policy which, amongst other things, identifies "English as the sole language of learning and tuition". ${ }^{178}$ The matter before the High Court concerned the reviewing and setting aside of the revised aforementioned language policy on grounds that it is inconsistent with the Constitution. ${ }^{179}$ The question before the Court was whether or not the policy can be justified under Section 29(2) of the Constitution. ${ }^{180}$ Similar to the Afriforum case $v$ University of Pretoria, the Court had to interpret Section 29 of the Constitution. In delineating what is reasonably practicable, as provided in the section, the court referred to Afriforum v University of Free State ${ }^{181}$ where the Court held that

"Reasonable practicability therefore requires not only that the practicability test be met, but also that considerations of reasonableness that extend to equity and the need to cure the ills of our shameful past, be appropriately accommodated. And that is achievable only if the exercise of the right to be taught in a language of a choice does not pose threat to racial harmony or inadvertently nurture racial supremacy" ${ }^{182}$

Additionally, the Court held that the element of reasonable practicability has to be appreciated as a polycentric inquiry, in other words, this element involves more than mere practicalities, in fact, key considerations of transformation and equity ought to be recognized. ${ }^{183}$

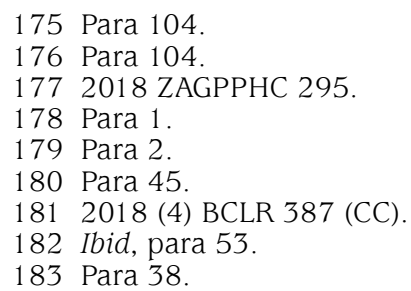


The Court asserted that, the right to be taught in a language of choice is not only dependent on the question whether existing resources make this technically practicable or possible. In other words, "even if it is technically practicable to provide teaching in a language of choice, the right to receive it may nonetheless be curtailed by the broader societal and constitutional considerations of equity and the need to redress past discrimination". 184

English has been accepted and a preferred language for communication, academia and business both locally and internationally ${ }^{185}$ thus making language equality is very important amongst all indigenous language. Considering Section 29 of the Constitution, in the distant future, South African Universities ought to get to a point where tuition can be provided in any language of choice. It is unacceptable that English language continues to be promoted at the expense of other languages. School and Higher education system, through the existence of political will from government, ought to apply systematic solutions aimed at redressing the oppression of indigenous languages in South Africa, more importantly, these solutions will not only advance both language and culture but promote acceptance of different languages and language equality.

What can be deduced from the foregoing discussion is that the courts were engaged in a rigorous process of balancing two competing rights (e.g. the use of English, Afrikaans, IsiXhosa and Isizulu languages). The Constitutional Court indicated that, in balancing the rights, various factors have to be taken into account such as "whether the desired ends could reasonably be achieved through other means less damaging to the right in question". ${ }^{186}$ It was evident in some cases that if the courts were to use Isizulu that would have brought more administrative challenges because of the lack of availability of resources such as transcribers from English to Isizulu including interpreters. ${ }^{187}$ However, where such right could be realised without further challenges, then such right could be readily provided for. ${ }^{188}$

184 Para 29

185 Para 33.

186 Sv Makwanyane and Another 1995 (6) BCLR 665 para 104.

187 Sv Makwanyane and Another para 104

188 SV Makwanyane and Another para 104 


\section{What can be learnt from the cases?}

The cases unfortunately do not provide a clear guidance about what should be done in the promotion of indigenous languages. Whilst some presiding officers have made initiative to make use of IsiXhosa in conducting the entire trial, there have been warnings from others that the use of other languages, other than English, may result in delays in the administration of justice because the resources to translate to other languages are not readily available.

Nonetheless, we are in support of the stance taken by the presiding officers who took an initiative to make use of indigenous languages, such as IsiXhosa, to conduct their trials. We submit that the Constitution can only be given effect to by individuals who are prepared to take unusual routes to ensure that the aspirations of the Constitution in so far as they relate to language are realised. We further submit that the language issue should not only be left at the hands of the courts, but the government also has a primary role to allocate resources for the fulfilment of her constitutional obligations.

We further applaud and encourage individuals and civil society organisations to stand up on matters that unfairly discriminate on the basis of language. In our view, all South Africans have been tasked with the promotion of languages. ${ }^{189}$ The Constitution requires everyone to play their role in achieving the aspirations that are set forth in the Constitution. ${ }^{190}$

\section{Efforts taken for the promotion of indigenous languages}

This section briefly discusses some of the measures that have been adopted by the South African government in order to promote the use of indigenous languages. The said steps include:

\section{Use of Official Languages Act 12 of 2012}

One of the objects of the Act includes to "promote parity of esteem and equitable treatment of official languages...". The Act applies to, amongst other things, national public entities, whilst section 4(1) "Every national department, national public entity and national public enterprise must adopt a language policy regarding its use of official languages".

189 The Preamble to the Constitution states that "We the people of South Africa" something that indicates collective responsibility to rebuild the country.

190 See Preamble to the Constitution. 


\section{The Language Policy Framework for Public Higher Education Institutions, determined in terms of section 27(2) of the Higher Education Act 101 of 1997 (as amended) ${ }^{191}$}

There are numerous South Africans who are unable to access higher education institutions due to language related barriers. The reality is that indigenous languages, despite their Constitutional recognition as official languages, have "not been afforded the official space to function as academic and scientific language". ${ }^{192}$

The underdevelopment and undervaluing of indigenous languages in higher education institutions is unacceptable, especially if these institutions "are to meet the diverse linguistic needs of their student population". ${ }^{193}$ If the predominant language spoken by the student population is a consideration when choosing a specific language as a medium of instruction, it is justifiable for the University of Venda to have Tshivenda as one of the languages for learning and teaching or Tshivenda as a medium of instruction.

Any language policy must take into consideration fundamental facets of the Constitution including, but not limited to, access, equity and inclusivity. ${ }^{194}$ Overall, it is the responsibility of government to create conditions for development and strengthening of indigenous languages, particularly for academic purposes. ${ }^{195}$

\section{Pan South African Language Board}

In an effort to develop previously marginalised languages, the Pan South African Language Board Act 59 of 1995 established the Pan South African Language Board (hereinafter the Board). ${ }^{196}$ The Board was established to promote respect for and ensure the implementation of the constitutional principles in section 3(9); to create condition for development and for the promotion of equal use and enjoyment of all official languages in South Africa; to prevent the use of any language for the purposes of exploitation, domination or division; to develop official languages in South Africa, promote respect for and the development of other languages used by communities in South Africa; promote the utilisation of South Africa's language resources. ${ }^{197}$

191 National Gazette No. 43858, 30 October 2020, Vol. 664.

192 Ibid, para 1.

193 Ibid, para 3.

$194 \mathrm{Ibid}$, para 15

195 Para 3.

196 Pan South African Language Board Act 59 of 1995.

197 Pan South African Language Board Act 59 of 1995. 


\section{Commission for the Promotion and Protection of the Rights of Cultural, Religious and Linguistic Communities}

The Commission is established by the Commission for the Promotion and Protection of the Rights of Cultural, Religious and Linguistic Communities Act 19 of 2002. The aims of the Commission include: promoting respect for and protection of rights of cultural, religious and linguistic communities; fostering mutual respect among cultural, religious and linguistic communities; and promoting the right of communities to develop their historically diminished heritage.

\section{Language Task Force}

Post-1994, it may be argued that not much has changed in the usage of indigenous languages, particularly in the education system. This lack of change is due to the justification of lack of state resources when there is a call for an indigenous language to be used as a medium language of instruction, particularly in communities where such language is widely spoken in the community. Furthermore, with all the admirable efforts by the state in establishing agencies and developing framework, these efforts must be accompanied by active political will. Additionally, snailpaced progress in indigenous language development hinders the promotion of indigenous languages.

It is acknowledged that the government has taken various measures to promote indigenous measures. However, we submit that such measures have not improved much, as indigenous languages, such as Isizulu or IsiXhosa, are not being used as primary modes of teaching in high schools and tertiary education. Instead, teaching and learning in most subjects and modules is offered in English.

\section{Conclusion and recommendations}

This decision is testimony that indigenous languages, such as IsiXhosa and Sesotho, at institutions of higher learning will take time to emerge and fully develop as they can only be offered provided that it is reasonably practical to do so. It must be noted that the use of Afrikaans in this present case was not put to an end. Rather, it is limited to certain circumstances such being applied only at undergraduate level. The State has a primary duty to develop indigenous languages at public institutions. ${ }^{198}$ The decision has also revealed that English continues to be given preference over indigenous languages. ${ }^{199}$ This is a major concern and a threat to the development of indigenous languages in

198 See s 6(2) of the Constitution of the Republic of South Africa Act 108 of 1996.

199 Languille "Affordable private schools in South Africa. Affordable for whom?" 2016 Oxford Review of Education 528. 
South Africa. ${ }^{200}$ Therefore, there is an urgent need for the State to develop other indigenous languages at institutions of higher learning.

In an effort to afford equal opportunities to the marginalised or disadvantaged people in society and enhance socio-economic conditions, one has to recognise and make usage of the contents of the South African Bill of Rights as a transformative document "aimed at achieving a society where people will be able to live their lives in dignity ...". ${ }^{201}$ Moreover, Jajbhay J made reference to the case of the Government of the Republic of South Africa and Others $v$ Grootboom and Others judgment ${ }^{202}$ asserting that the judgment:

"[c]onfirms that the full transformative power of the rights in the Bill of Rights will only be realised when they are interpreted with reference to the specific social and economic context prevalent in the country as a whole, and the social and economic context. There are vast social and economic inequalities between different groups that leave many people extremely vulnerable and even desperate, far removed from the ideal of a life lived in dignity and respect. This approach acknowledges that people cannot live with a semblance of human dignity and cannot fulfil their full potential as human beings where structural inequality prevails and where the State fails to take steps to address such structural inequality and its causes."203

In light of the above, it is in our view unacceptable that twenty five years into constitutional democracy there is still little or no progress in having one of indigenous languages such as Sesotho or IsiXhosa as a primary language of tuition in one of the institutions of higher learning. In our view, this is a matter that needs to be addressed and cannot forever remain at the mercy of those who are tasked with driving language policies in institutions of higher learning.

The Constitution is clear in that all stakeholders, Black, White, and Brown united in their diversity, have a collective responsibility to build a South Africa that belongs to all wherein people can fully realise their potential through the enjoyment of their human rights including the protection and promotion of their indigenous languages. ${ }^{204}$

Perhaps, the time has also come wherein the Constitutional Court will issue its judgments in other indigenous languages. In our view, the Court should not only be seen in advocating for indigenous languages in theory but should also deliver its judgments in other indigenous languages.

200 Languille 2016 Oxford Review of Education 528.

201 Government of the Republic of South Africa v Grootboom 200011 BCLR 1169.

202 Government of the Republic of South Africa v Grootboom supra.

203 See City of Johannesburg $v$ Rand Properties (Pty) Ltd 20066 BCLR 728 (W) para 51.

204 See Preamble of the Constitution of the Republic of South Africa, 1996. 